\title{
CORRECTION
}

\section{Correction to: Digital Tools for the Self-Assessment of Visual Acuity: A Systematic Review}

Janneau L. J. Claessens (D) - Judith R. Geuvers - Saskia M. Imhof •

Robert P. L. Wisse (1)

Published online: July 31, 2021

(c) The Author(s) 2021

Correction to: Ophthalmol Ther https://doi.org/

$10.1007 / \mathrm{s} 40123-021-00360-3$

In Fig. 4 of this article, the 95\%LoA are not properly visualized for three studies (Muijzer 2021, VA $\leq 0.5 \log$ MAR; Rosser 132001 [ETDRS] and Lim 2010 [ETDRS]); the figure should have appeared as shown below.

The original article has been corrected.

The original article can be found online at https://doi. org/10.1007/s40123-021-00360-3.

J. L. J. Claessens ( $₫)$ S. M. Imhof · R. P. L. Wisse Department of Ophthalmology, University Medical Center Utrecht, Heidelberglaan 100, 3508 GX

Utrecht, The Netherlands

e-mail: j.l.j.claessens@umcutrecht.nl

J. R. Geuvers

Faculty of Medicine, Utrecht University, Utrecht,

The Netherlands 


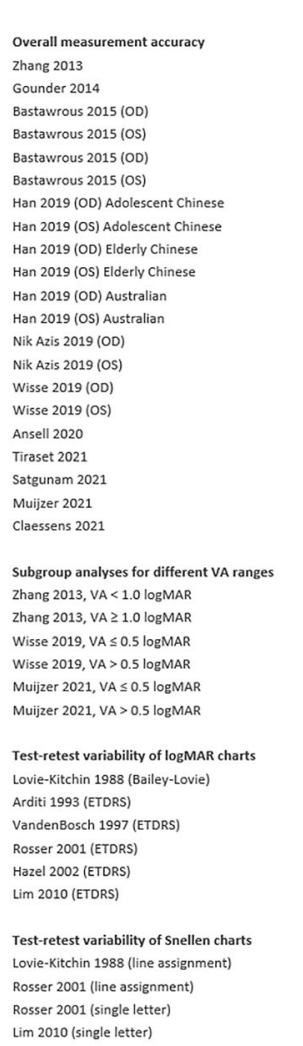

\begin{tabular}{|c|c|}
\hline $\mathrm{N}$ & Name of the digital tool \\
\hline 240 & Eye Chart Pro \\
\hline 122 & EyeSnellen app \\
\hline 272 & Peek Acuity \\
\hline 272 & Peek Acuity \\
\hline 272 & Peek Acuity \\
\hline 272 & Peek Acuity \\
\hline 50 & Vision@Home \\
\hline 50 & Vision@Home \\
\hline 50 & Vision@Home \\
\hline 50 & Vision@Home \\
\hline 63 & Vision@Home \\
\hline 63 & Vision@Home \\
\hline 195 & AAPOS Vision Screening \\
\hline 195 & AAPOS Vision Screening \\
\hline 97 & Easee \\
\hline 97 & Easee \\
\hline 24 & Eye Chart \\
\hline 295 & Eye Chart \\
\hline 68 & Peek Acuity \\
\hline 84 & Easee \\
\hline 98 & Easee \\
\hline 182 & Eye Chart Pro \\
\hline 58 & Eye Chart Pro \\
\hline 125 & Easee \\
\hline 64 & Easee \\
\hline 43 & Easee \\
\hline 41 & Easee \\
\hline \multicolumn{2}{|c|}{115} \\
\hline \multicolumn{2}{|l|}{78} \\
\hline \multicolumn{2}{|l|}{70} \\
\hline \multicolumn{2}{|l|}{41} \\
\hline \multicolumn{2}{|l|}{40} \\
\hline \multicolumn{2}{|l|}{40} \\
\hline \multicolumn{2}{|c|}{115} \\
\hline \multicolumn{2}{|l|}{41} \\
\hline 41 & \\
\hline 40 & \\
\hline
\end{tabular}

Fig. 4 Mean differences between distance visual acuity assessments (digital tool minus reference standard) and 95\% limits of agreement in $\log$ MAR. Some articles reported separate comparisons per subgroup or per eye. The dashed lines represent $\pm 0.15 \log M A R$, a difference

\section{OPEN ACCESS}

This article is licensed under a Creative Commons Attribution-NonCommercial 4.0 International License, which permits any noncommercial use, sharing, adaptation, distribution and reproduction in any medium or format, as long as you give appropriate credit to the original author(s) and the source, provide a link to the Creative Commons licence, and indicate if changes were made. The images or

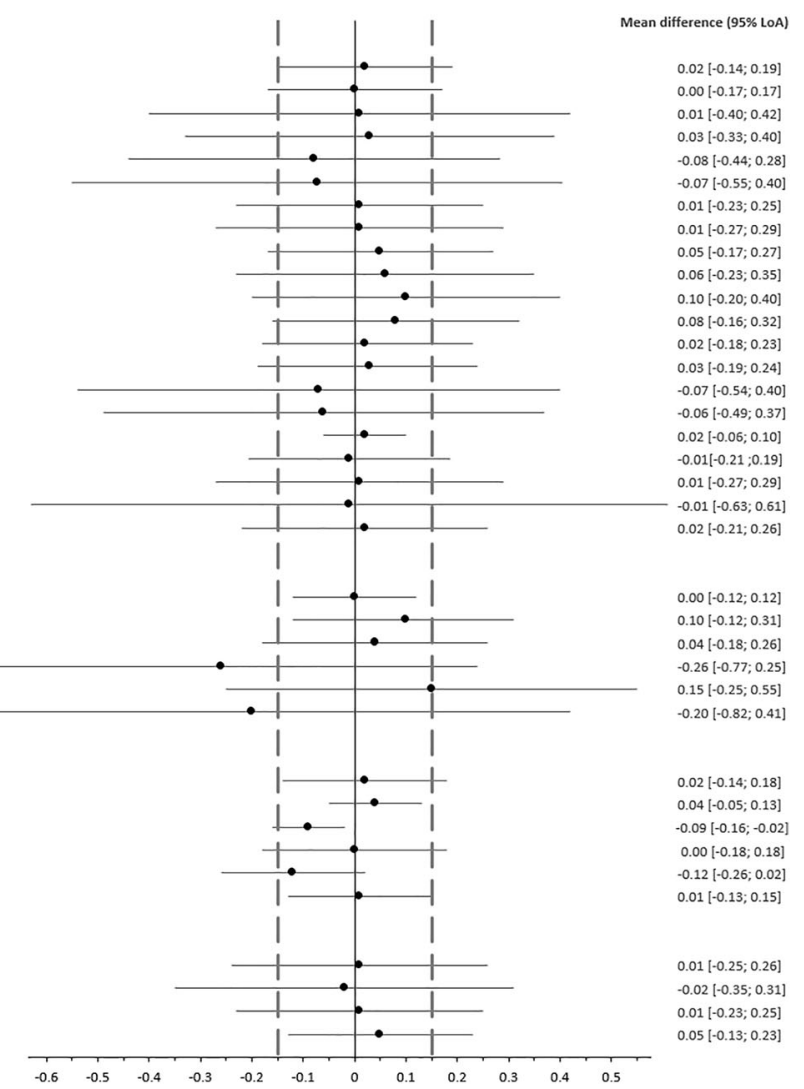

that has been suggested in literature to be clinically acceptable [20]. Abbreviations: $N$ number of paired observations; 95\% LoA 95\% limits of agreement

other third party material in this article are included in the article's Creative Commons licence, unless indicated otherwise in a credit line to the material. If material is not included in the article's Creative Commons licence and your intended use is not permitted by statutory regulation or exceeds the permitted use, you will need to obtain permission directly from the copyright holder. To view a copy of this licence, visit http://creativecommons.org/licenses/by$\mathrm{nc} / 4.0 /$. 